Endocrinol. Japan., Vol. 2, No. 4 (1955).

\title{
TAYROID STIMULATING HORMONE EXTRAGTED FROM HUMAN PLACENTA
}

\author{
FUMIO AKASU, SETSU KAWAHARA, HIROSHI OHKI, \\ MICHIKO HARANO AND YOKO TEJIMA
}

(Director Prof. F. Akasu)

\author{
Department of Obstetrics $\&$ Gynecology, School of \\ Medicine, Toho University
}

\section{SEVEN FIGURES}

In spite of many investigations, it has not yet been settled whether the activity of the adenohypophysis is increased or decreased during pregnancy. Gonadotrophin in human pregnancy urine is believed to be secreted from the placenta and not from the adenohypophysis. Since the steroid hormones increase in the circulating blood with the progress of pregnancy, it seems not unlikly that the activity of the adenohypophysis is depressed during pregnrncy.

It seems likely that the placenta produces many trophic hormones just like the adenohypophysis. Besides gonadotrophin, ACTH has already been extracted from the placenta (Opsahl, Long and Fry, 1951 ; Akasu and Miyakawa, 1953; Akasu, Takeuchi and Miyakawa, 1954).

There have been various reports which suggest that the function of the thyroid gland is increased during pregnancy. For examples, it has been reported that during pregnancy the thyroid gland is hypertrophid (Mussey, 1938), B. M. R. is increased (Javert, 1940), I131 uptake is increased (Hertz, 1946) and protein bound iodide (PBI) level is elevated (Peters, Man and Heineman, 1948; Heineman, Johnson and Man, 1948 ; Danowski, Gow, Mateer et al., 1950).

In this paper the extraction of TSH-like substance from the human placenta will be reported.

\section{MATERIAL AND METHOD}

Fresh human placentae which were obtained by cesarean section in the late stage of pregnancy without toxemia symptom were used.

Extraction of TSH from the placenta was carried out at first by a modified Loeser's method (1932; Akasu, 1955). As this method was found to be not very efficient, later on Ciereszko's method was used for the extraction.

Bioassay was carried out by Junkmann-Schoeller's method (1922) using young guinea-pig. Proper dose of the extract was injected subcutaneously daily for three days. On the fourth day test animals were killed, blood specimens were taken for PBI determination, and the thyroid glands were extirpated and examined histologically by the Haematoxylin-eosin technic.

Determination of PBI was carried out by Baker's method (1951). Serum cholesterol was measured by Bloor's method (1922, 1928).

Received for publication Dec. 15, 1955. 


\section{RESULTS}

\section{I) Results using the TSH-like substance extracted by Loeser's method}

Three-hundred and fifteen $\mathrm{mg}$. of slightly brown coloured, fine homogenous and water soluble powder was obtained from $350 \mathrm{~g}$. of human placenta.

The change of PBI level and the histological finding of the thyroid gland in guinea-pigs administered proper doses of this extract are shown in Table 1 and Figs. 1, 2 and 3.

Table 1. Effect of administration of placental TSH on the PBI level and thyroid histology in guinea-pigs (Loeser's method).

\begin{tabular}{|c|c|c|c|c|c|}
\hline $\begin{array}{l}\text { Daily } \\
\text { dose } \\
\text { (mg.) }\end{array}$ & $\begin{array}{l}\text { Body } \\
\text { weight } \\
\text { (g.) }\end{array}$ & $\begin{array}{c}\text { PBI } \\
(\gamma / \text { dl. })\end{array}$ & $\begin{array}{l}\text { Histological } \\
\text { Epithelium of } \\
\text { follicles }\end{array}$ & $\begin{array}{l}\text { findings of th } \\
\text { Content of } \\
\text { colloid }\end{array}$ & $\begin{array}{l}\text { Dilatation of } \\
\text { capillary nets }\end{array}$ \\
\hline \multirow{2}{*}{0.5} & 199 & 3.4 & \multirow{2}{*}{$\begin{array}{l}\text { low } \\
\text { cuboidal } \\
\quad 1 /\end{array}$} & rich & - \\
\hline & 197 & 3.3 & & "I & "I \\
\hline 1.0 & $\begin{array}{l}210 \\
197 \\
\end{array}$ & 3.5 & "I & "I & 11 \\
\hline \multirow[t]{2}{*}{1.5} & 182 & 3.3 & \multirow{2}{*}{$\begin{array}{l}\text { low } \\
\text { cuboidal } \\
\end{array}$} & rich & - \\
\hline & 200 & 3.6 & & "I & "I \\
\hline 2.0 & $\begin{array}{l}181 \\
215\end{array}$ & 3.5 & & & \\
\hline \multirow[t]{2}{*}{3.0} & 160 & 3.6 & \multirow{2}{*}{$\begin{array}{l}\text { *columnar, } \\
\text { folded, } \\
\text { hypertrophied } \\
\text { // }\end{array}$} & $\begin{array}{l}\text { smal' }^{\prime} \\
\text { amount }\end{array}$ & $H$ \\
\hline & 162 & 4.1 & & "I & $/ 1$ \\
\hline \multirow{2}{*}{5.0} & 172 & 3.9 & \multirow{2}{*}{$\begin{array}{l}* \\
\end{array}$} & "I & + \\
\hline & 176 & 3.6 & & "I & "I \\
\hline \multirow{3}{*}{ control } & 151 & 3.3 & \multirow{3}{*}{$\begin{array}{c}\text { *low } \\
\text { cuboidal } \\
\text { " } \\
\text { " }\end{array}$} & rich & - \\
\hline & 225 & 3.1 & & rich & "I \\
\hline & 217 & 3.4 & & "I & "I \\
\hline \multirow[t]{2}{*}{ Pregnant } & 760 & 4.7 & \multirow{2}{*}{$\begin{array}{l}\text { columnar, } \\
\text { folded, } \\
\text { hypertrophied } \\
\quad \text { // }\end{array}$} & $\begin{array}{l}\text { small } \\
\text { amount }\end{array}$ & H \\
\hline & 600 & 4.0 & & "I & $" 1$ \\
\hline
\end{tabular}

* Histological pictures of these cases were shown in Figs. 1, 2 and 3.

The PBI levels of all guinea-pigs administered the TSH-like substance were elevated compared with that of control animals.

Thyroid glands of the guinea-pigs administered less than $2.0 \mathrm{mg}$. of the TSHlike material daily showed no hyperfunctioning figures, but those receiving more than $3.0 \mathrm{mg}$. showed the histological pictures of hyperfunction. The epithelium of follicles was thickend, folded and hypertrophied. Colloid was decreased in amount, and the capillary nets were dilated. 

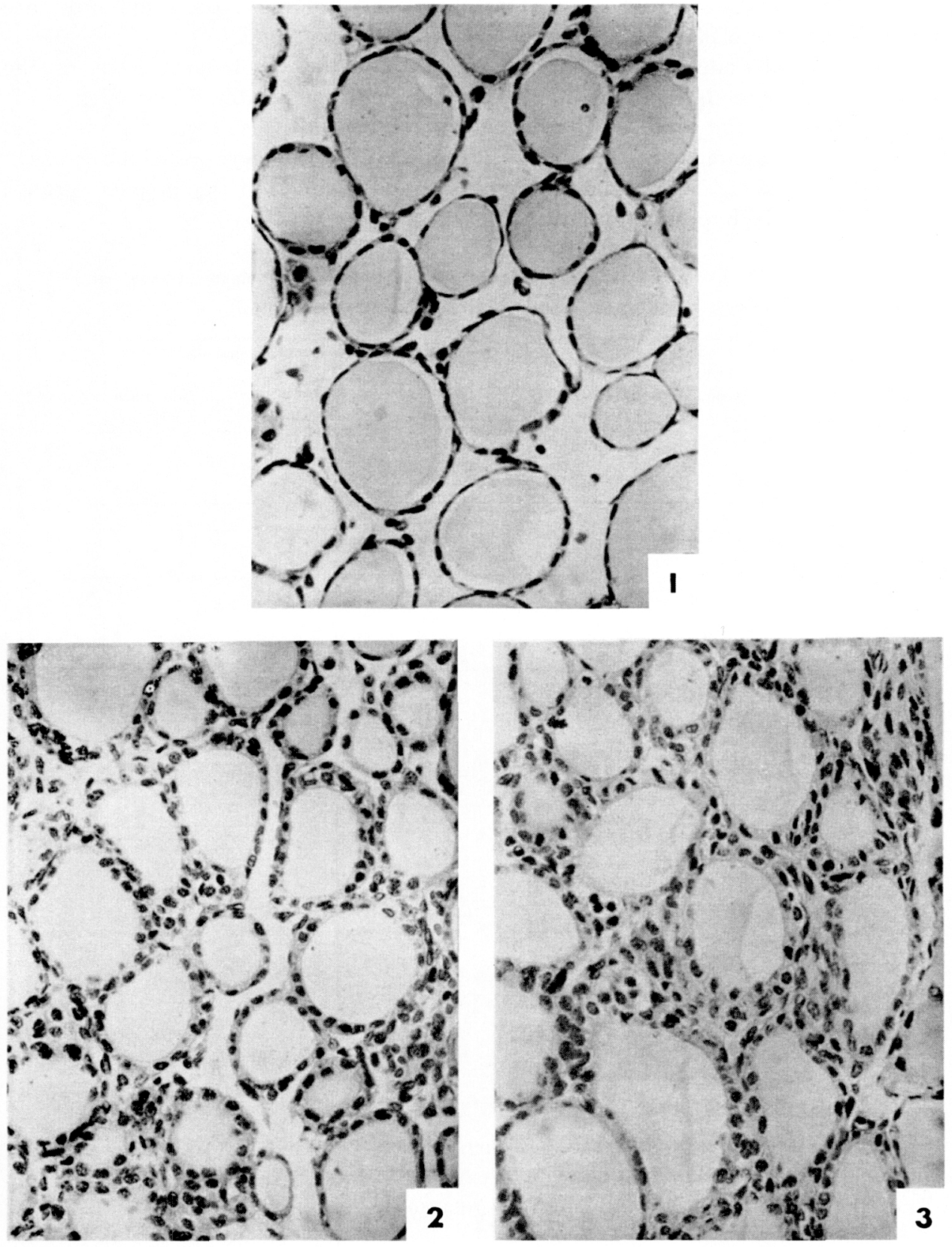

Fig. 1. Thyroid of control guinea-pig

Fig. 2. Thyroid of guinea-pig which received P-TSH (daily dose $3.0 \mathrm{mg}$.)

Fig. 3. Thyrold of guinea-pig which received P-TSH (daily dose $5.0 \mathrm{mg}$.) 
II) Results using the TSH-like substance extracted by Ciereszko's method

Sixty-one mg. of white, transparent and water soluble lyophilized substance was obtained from $900 \mathrm{~g}$. of human placenta by this method.

Histological findings of the thyroid glands and the cholesterol level of the serum of test animals receiving the extract are shown in Table 2 and Figs. 4 7.

As shown in the table, the serum cholesterol level in the injected groups fell significantly compared with the control group, except in the groups which received $0.1 \mathrm{mg}$. and $0.25 \mathrm{mg}$. of the material. The thyroid glands in the injected groups showed distinctly hyperfunctioning pictures.

Table 2. Effect of administration of placental TSH on the cholesterol level and thyroid histology in guinea-pigs. (Ciereszko's method).

\begin{tabular}{|c|c|c|c|c|c|}
\hline $\begin{array}{l}\text { Daily } \\
\text { dose } \\
\text { (mg.) }\end{array}$ & $\begin{array}{l}\text { Body } \\
\text { weight } \\
\text { (g.) }\end{array}$ & $\begin{array}{l}\text { Total } \\
\text { cholesterol } \\
(\mathrm{mg} \cdot / \mathrm{dl} .)\end{array}$ & $\begin{array}{l}\text { Histological } \\
\text { Epithelium of } \\
\text { follicles }\end{array}$ & $\begin{array}{l}\text { finding of thyro } \\
\text { Content of } \\
\text { colloid }\end{array}$ & $\begin{array}{l}\text { id gland } \\
\text { Dilatation of } \\
\text { capill. nets }\end{array}$ \\
\hline \multirow[t]{2}{*}{0.1} & 103 & 75.5 & \multirow[t]{2}{*}{$\begin{array}{l}\text { low } \\
\text { cuboidal }\end{array}$} & rich & - \\
\hline & 88 & 110 & & " & " \\
\hline \multirow[t]{2}{*}{0.25} & 97 & 87.5 & \multirow{2}{*}{$\begin{array}{l}\text { columnar, } \\
\text { hypertrophied } \\
\text { /" }\end{array}$} & "I & - \\
\hline & $* 119$ & 95.5 & & " & 11 \\
\hline \multirow[t]{3}{*}{0.5} & ${ }^{*} 146$ & 67.5 & \multirow{3}{*}{$\begin{array}{l}\text { columnar, } \\
\text { hypertrophied } \\
\text { " } \\
\text { "/ }\end{array}$} & dereased & + \\
\hline & 143 & 62.5 & & "I & " \\
\hline & & 72.0 & & rich & \pm \\
\hline \multirow{4}{*}{1.0} & 113 & 62.5 & $\begin{array}{l}\text { columnar, } \\
\text { hypertrophied } \\
\text { folded }\end{array}$ & decreased & $H$ \\
\hline & ${ }^{*} 121$ & 27.5 & "I & "I & "I \\
\hline & 113 & 45.0 & "I & "I & " \\
\hline & 107 & 55.5 & "I & 11 & " \\
\hline \multirow{4}{*}{3.0} & 142 & 65 & "I & "I & "I \\
\hline & * 142 & 57.5 & $" 1$ & " & " \\
\hline & 123 & 62.5 & " & "I & "I \\
\hline & 121 & 67.5 & "I & "l & + \\
\hline \multirow[t]{3}{*}{ control } & 150 & 100 & \multirow{3}{*}{$\begin{array}{c}\text { low } \\
\text { cuboidal } \\
\text { " } \\
" 1\end{array}$} & rich & - \\
\hline & 149 & 85 & & "I & " \\
\hline & 134 & 80 & & "I & " \\
\hline
\end{tabular}

* Fig. cases

\section{DISGUSSION}

The function of adenohypophysis during pregnancy has not yet been understood clealy but there are many evidences which show that the activity of the adenohypophysis is decreased during pregnancy.

On the other hand, increase of thyroid activity during pregnancy has been confirmed by many experimental studies. As there is no evidence that the adenohypophysis secretes more $\mathrm{TSH}$ during pregnancy than usual, these facts suggest that the origin of TSH during pregnancy is extraadenohypophyseal. 

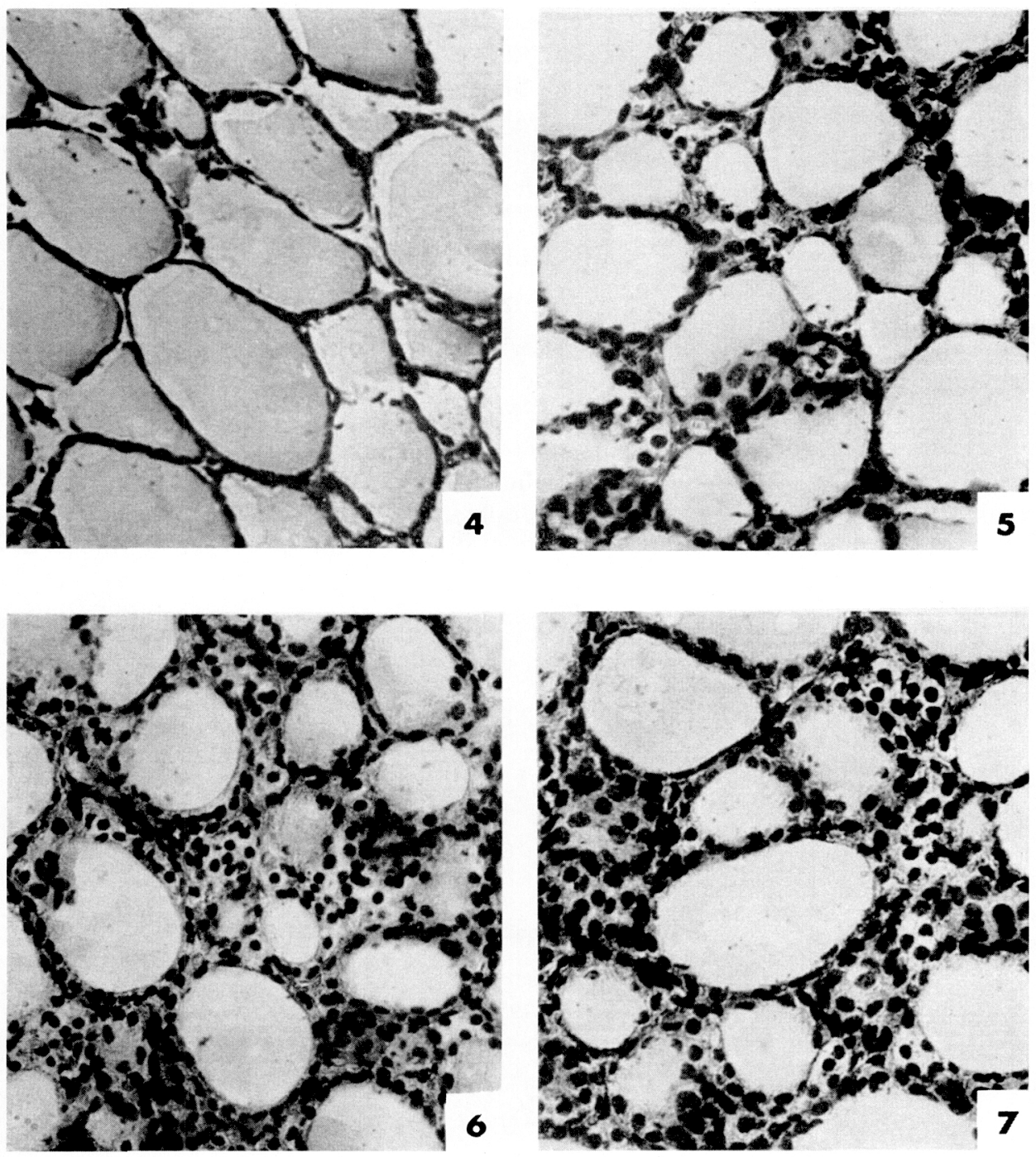

Fig. 4. Thyroid of control guinea-pig

Fig. 5. Thyroid of guinea-pig which received P-TSH (daily dose $0.25 \mathrm{mg}$.)

Fig. 6. Thyroid of guinea-pig which received P-TSH (daily dose $1.0 \mathrm{mg}$.)

Fig. 7. Thyroid of guinea-pig which received P-TSH (daily dose $3.0 \mathrm{mg}$.) 
It is well known that the placental extract has a luteinizing hormone (LH) like activity. Moreover, we have demonstrated the placental follicle stimulating hormon (FSH). ACTH has also been extracted from the placenta (Opsahl, Long and Fry, 1951 ; Akasu and Miyakawa, 1953; Akasu, Takeuchi and Miyakawa, 1954). In this paper, the placental TSH has been demonstrated. We presume that growth hormone and prolactin will be extracted from the placenta in the near future. In our opinion, the placenta is the second adenohypophysis and it functions in stead of adenohypophysis during pregnancy.

\section{SUMMARY}

1) Three hundred and fifteen $\mathrm{mg}$. of TSH-like substance has been obtained from $350 \mathrm{~g}$. of human placenta by Loeser's method. Sixty-one mg. of the similar substance has been extracted from $900 \mathrm{~g}$. of placenta by Ciereszko's method.

2) By the administration of this TSH-like substance to guineapigs, an elevation of the PBI level and a decrease in serum cholesterol were caused.

3) Distinctly hypertrophied and columnar cells of the epithelium of follicles, small amount of colloid in the follicles, dilatation of capillary nets in the guineapigs thyroid glands were observed histologically after administration of the TSHlike substance.

4) We propose the name P-TSH (placental thyroid stimulating hormone) for this substance.

\section{REFERENCES}

Akasu, F. : N. S-F. GK. Z. (Jap. J. Obst. \& Gynec.) $7: 655,1955$.

Akasu, F. and K. Miyakawa: N. S-F. GK. Z. (Jap. J. Obst. \& Gynec. 5 : 953, 1953.

Akasu, F., M. Takeuchi and K. Miyakawa: Hormon to Rinsho 2: 1082, 1954.

Baker, S. B. and M. J. Humphrey : J. Clin Endocrinol. 10: 1136, 1950.

Bloor, W. R. : J. Biol. Chem. 24: 227, 1916.

Bloor, W. R. : ibid. $77: 53,1928$.

Bloor, W. R., K. F. Pelkan and D. M. Allen: J. Biol. Chem. 52: 191, 1922.

Ciereszko, L. S. : J. Biol. Chem. 160 : 585, 1945.

Danowski, T. S., R. C. Gow, F. M. Mateer, W. C. Everhart, S. Y. Johnston and J.H. Greenman: Proc. Soc. Exp. Biol. and Med. 74: 323, 1950.

Heineman, M., C. E. Johnson and E. B. Man : J. Clin. Investig. 27: 91, 1948.

Hertz, S. : Am. J. Physiol. 128 : 565, 1946.

Javert, C. T. : Am. J. Obst. and Gynec. 39 : 954, 1940.

Junkmann, K. and W. Schoeller: Klin. Wschr. 11: 1176, 1932.

Loeser, A. : Klin.Wschr. 11: 1271, 1932.

Mussey, R. O. : Am. J. Obst. and Gyne. 36 : 529, 1938.

Opsahl, J. C., C. N. H. Long and E. G. Fry: Yale J. Biol. Med. 23 : 399, 1951.

Peters, J. P., E. B. Man and M. Heineman: ibid. 20: 449, 1948.

Philipp, E. : Zbl. Gynaek. 8 : 450, 1930.

Philipp, E. : ibid. 30 : 1858, 1930. 